\section{"Dark nature"}

\section{- Rapid natural} changes,

\section{catastrophes, and}

\section{human responses}

Nature is not always the benign provider of shelter and the carer of all needs. It has a dark side, capable of extreme and sudden geological violence-earthquakes, eruptions, floods. Less violent but on occasion also harmful to people and biota are changes to coastlines, river channels, sand dunes, groundwater and karst and permafrost terrains, geological processes that can take place on time scales of decades, years or less.

In recognition of the harmful side of rapid natural change, the International Council for Science (ICSU) and the International Geological Correlation Programme are now funding two new scientific ventures. The ICSU project, which will run from 2004 to 2005, is entitled "Dark nature: rapid natural change and human responses". This is a follow-up to a very stimulating interdisciplinary conference held at Brunel University, UK, in 2002 on Holocene catastrophes and recoveries. Championed by INQUA, the ICSU grant was awarded to IUGS as the lead applicant, through its Geoindicator Initiative, with support from INQUA, IGU, IUGG, IGBP, and several other organizations. The ICSU project will cooperate very closely with IGCP Project 490 "The role of Holocene environmental catastrophes in human history", approved recently by IUGS for the period 2003 to 2007. Both projects will organize research conferences and scientific publications, with an interdisciplinary scope extending from the earth sciences and geography into archaeology, anthropology, and ecology.

A main goal of the two projects is to refine the record of rapid environmental changes affecting physical environments and ecosystems during the last 11,500 years (the Holocene). They will examine how past societies and communities reacted in the face of harmful change, and will explore the implications of rapid natural change for current environmental and public policies.

While recognizing that there are many interactions with anthropogenic stresses and biological processes, the projects will concentrate on rapid earth processes that are dominantly abiotic (physical and chemical), whether climate-driven or not. The direct effects of both abiotic and biotic factors on society will be considered, within a broad context where environmentally-driven societal changes have occurred. One focus will be the identification of the natural stresses involved, so as to contribute to a better understanding of the effects of environmental disturbances. Are there acute societal responses to a single landscape change, or do communities respond to cumulative or convergent disturbances that affect a climatically-stressed landscape, as in a volcanic eruption? Alternatively, where there is environmental evidence for rapid natural disturbance, can archaeological or anthropological 'imprints' of human adaptation to it be detected? If so there may be valuable lessons for contemporary climate and environmental change.

Though the timescale of these environmental changes may well exceed that of political and economic planning (typically 35 years), there are important implications in the policy arena concerning, for example, the restoration and management of landscapes and resource management. A main goal is to share and communicate the significance of what science is revealing about the character and effects of harmful rapid environmental change.

The initial meetings are currently being organised. The first will be in Mauritania in January 2004 where scientists will forget about electricity and venture into the Saharan desert either on camels back or in four wheeldrive vehicles. Out in the desert, under the shelter of an acacia tree, presentations and discussions will be held on desertification, coastal wetland protection, ground water, and the collapse of past civilisations. The second meeting will be held in Turkey in June 2004 and will bring earth scientists, archaeologists and anthropologists together to examine human responses to past rapid environmental change in the ancient world. After the three-day discussion meeting, a field trip will take participants around some of the spectacular cultural and geological sites of western Turkey. Other meetings are planned for Madagascar-Mozambique and Argentina in autumn 2004, and the Canadian Arctic in summer 2005. A major symposium will be held in Como, Italy, in autumn 2005 to wrap up the ICSU project. The IGCP 490 programme will have additional meetings in Papua-New Guinea in 2006 and Egypt in 2007.

For further information contact Professor Suzanne Leroy (Department of Geography and Earth Sciences, Brunel University, Uxbridge,UK.

Suzanne.Leroy@brunel.ac.uk), the Leader for the ICSU project and co-leader of IGCP 490 with Dr Iain Stewart (University of Glasgow, istewart@geog.gla.ac.uk ).

\section{Professor Suzanne Leroy}

Department of Geography and Earth Sciences Brunel University

Uxbridge

UK

\section{The first "Golden Spike" within Cambrian}

The International Union of Geological Sciences (IUGS) has recently ratified the Global Standard-stratotype Section and Point (GSSP) for the base of Paibian Stage and Furongian Series proposed by a Sino-U.S team with Peng Shanchi, Nanjing Institute of Geology and Palaeontology (NIGPAS), L. E. Babcock, the Ohio State University, Columbus, Ohio (OSU), R. A. Robison, the Kansas University, Lawrence, Kansas, Lin Huanling (NIGPAS), M. N. Rees, the Nevada University, Las Vegas, Nevada, and M. R. Saltzman (OSU). This is the first intra-Cambrian GSSP for the Cambrian System, and the Paibian and the Furongian are known respectively as the first formal Stage and the first formal Series within Cambrian.

Until Prof. Peng's proposal was voted in June, 2002 by the International Commission on Stratigraphy, there had not been any formally agreed international subdivisions in the Cambrian System. This partly reflects the scarcity of suitable biostratigraphic markers for intercontinental correlation at the series and stage level.

The stratotype section of Paibian Stage and Furongian Series is situated near Paibi, a small town in Huayuan County, northwestern Hunan Province, South China. Its geographic coordinates are latitude $28^{\circ} 23^{\prime} .37^{\prime \prime} \mathrm{N}$, longitude $109^{\circ} 31^{\prime} 54^{\prime \prime} \mathrm{E}$. The base of the Paibian Stage (also the base of the Furongian), is defined at $369.06 \mathrm{~m}$ above the base of the Huaqiao Formation in the Paibi section, corresponding to the First Appearance Datum (FAD) of cosmopolitan agnostoid trilobite Glyptagnostus reticulatus (Angelin), which is within a continuous evolutionary sequence of Glyptagnostus species. The base of Paibian closely corresponds with the onset of a large positive shift of $\delta^{13} \mathrm{C}$ values referred to as Steptoean positive carbon isotope excursion (the SPICE excursion).

\section{Peng Shanchi}

Nanjing Institute of Geology and Paleontology Nanjing 210008

CHINA

E-mail: scpeng@nigpas.ac.cn

Loren E. Babcock

The Ohio State University Columbus, $\mathrm{OH} 43210$

USA

E-mail:babcock.5@osu.edu 


\section{Orbituary}

\author{
Nikita A. Bogdanov \\ Secretary-General of 27 th \\ IGC
}

Professor Nikita A.Bogdanov, an outstanding geologist well-known in the international geological community, passed away on December 142003 in Moscow after a brief but serious disease.

N.Bogdanov was born on July 23, 1931 to a family of the eminent Russian geologist Alexey Alexeevich Bogdanov, Dean of the Geological Faculty of the Moscow State University, Secretary General of the CGMW Subcommission for Tectonic Maps.

After graduating from the Moscow Geological Prospecting Institute, Nikita Bogdanov started his scientific work at the Geological Institute of the USSR Academy of Sciences, where he was involved in the research of then poorly investigated regions of the Russian Far East. With these and adjacent Northeast and Arctic regions he was associated throughout his entire professional career. He took a strong interest in the Cir-

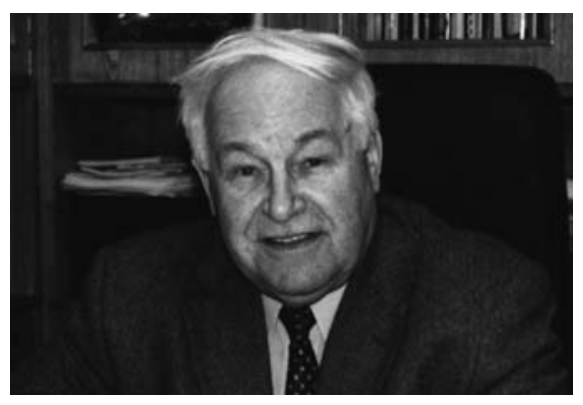

cum-Pacific Belt, to which he devoted his doctoral thesis.

Another challenging problem for Prof. Nikita Bogdanov was that of ophiolites, in which he achieved substantial progress. He initiated an international project on ophiolites that successfully worked for many years.

He was a participant and leader of a number of marine expeditions.

His exceptional organizational capabilities ensured the success of the 27th International Geological Congress in 1984, of which he was General Secretary. He participated in many international geological programs and projects, including those pertaining to deepsea drilling.

In 1979, when the Institute of the Lithosphere was founded, Alexandr V. Sidorenko, Member of the USSR Academy of Sciences and Director of the Institute at that time invited N.Bogdanov to be Deputy Director of the Institute. Later Bogdanov became its Director and remained in that capacity till his last days. One of the main objectives of the Institute was the preparation of tectonic maps of the Barents, Kara, Laptev, Okhotsk, Caspian and Mediterranean Seas. In 2002, Prof. N.Bogdanov received the State Prize of the Russian Federation for that work. In 1990 he was elected corresponding member of the USSR Academy of Sciences. N.Bogdanov was also professor of the Moscow State University.

He has greatly contributed to research of the extensive region of Russia and furthering international cooperation in earth sciences.

His broad knowledge, high professional level, amazing gift of communication, optimism and ability to bring out the best in people earned for him the respect and admiration of his colleagues and everyone, who had known and cooperated with him. We shall remember N.Bogdanov as an outstanding scientist and inspiring and unfailing friend.

\section{Victor E.Khain}

Member of the Russian Academy of Scences

\section{Episodes is your window to the world. Subscribe today! Episodes}

\section{Subscription Order}

Name (please print)

Address

City State/Prov.

Country Zip/Postal Code

Please begin my subscription:

$\begin{array}{llll}\text { March } & \text { June } & \text { Sept. } & \text { Dec. } \\ \text { Year } & \text { Year } & \text { Year } & \text { Y Year }\end{array}$

To start your subscription, fill in this form and mail to:

\section{Episodes}

P.O. Box 823

26 Baiwanzhuang Rd.,

Beijing 100037, China

Tel: +86-10-6832 0827; +86-10-68329084

Fax: +86-10-6832 8928

E-mail:episodes@public2.bta.net.cn
Payment may be made by:

- Checks (US \$ only) made payable to Episodes

- $\square$ Diners $\square$ JCB $\square$ Visa $\square$ American Express $\square$ Mastercard

Please quote account number, expiry date and signature.

Account\#

Expiry date

Signature

Annual subscription rates: US\$ 24 